\title{
ANALYSIS OF REVENUE GENERATION AND SERVICE DELIVERY IN IBARAPA CENTRAL LOCAL GOVERNMENT, IGBOORA, OYO STATE (2010-2014)
}

\author{
Oyetunde Ojo*, Oyedele Kayode Samson**
}

\begin{abstract}
Research aims. This study focuses on the relationship between revenue generation and service delivery in Ibarapa Central Local Government, Igboora, Oyo State, Nigeria (2010-2015) . It identifies the various sources of revenue generation of the local government and analyses the effect of each one on service delivery. It also examines the factors militating against the effectiveness of the various sources and recommend how they can be improved upon.
\end{abstract}

Methodology. The methodology of the study is secondary relying on the local government internally generated revenue documents, departmental expenditure account documents, statutory allocation records, ledgers, cash books and annual budget estimates between 2010-2014. Descriptive Statistical tools of percentages, frequency and table distribution as well as inferential statistical tools of Analysis of Variance (ANOVA) were used to interpret the data. The result of tested hyphotesis $(\mathrm{F}=2.154$ at 0.05 level of significance) indicates that there is relationship between Internally Generated Revenue (IGR) and Service Delivery in Ibarapa Central Local Government, Igboora. However, the relationship does not have the desired effect in the local government because of the paltry sum of the Internally Generated Revenue (IGR).

Key findings. The heuristic values of the study are thrice fold. First, it will deepen knowledge on the role and importance of local government generally as an agency of public finance. Also, it will provide an insight on how strategies can be devised on the improvement of their internally generated revenue. Third, it will provide input on how local governments generally can be more judiciously, effectively and efficiently managed.

Key words: Internally Generated Revenue, efficiency, effectiveness, Ibarapa Central Local Government, Nigeria

\footnotetext{
* Ladoke Akintola University of Technology, Ogbomoso, Oyo State, Nigeria. E-mail: oyetundeoluojo@gmail.com

** Ladoke Akintola University of Technology, Ogbomoso, Oyo State, Nigeria. E-mail: ksoyedele@gmail.com
} 


\section{INTRODUCTION: BACKGROUND TO THE STUDY}

The main idea behind the existence of local government either in federalism as the third tier government, coordinate and autonomous, or in unitarism as an agent of deconcentration, is to bring government closer to the people (Ibok, 2014). Getting government nearer to the people implies the provision of the basic infrastructure and amenities of life at the grassroots. These are socio-economic goods and services which are either too remote to attract the attention of the central government, or that the central government is overburdened, overloaded, overbureaucratised and under-responsive to such matters. Yet about $70 \%$ of the population lives in rural areas where the necessity arises for the provision of such social goods and public services (Ekpe, Daniel, \& Ekpe, 2013).

In other words, one of the raison d'êtres for the creation of local government is the belief that it is in the best position to create and sustain rapid socio-economic and political development. This is by utilising internally generated funds to complement the state's and federally allocated finances at the grassroots levels (Coker, Eteng, Agishi, \& Adie, 2015). The local councils are also best placed to manage the difficult trade-offs which invariably have to be made when making choices at the local level. This is because governments at the local level often engage with local communities to feel their pulse, understand their needs, priorities and preferences. This will enable the local councils deduce the host communities well-informed choices of resource allocation in the most efficient and satisfactory manner. This is the reason Akindele (2004) contends that local government institutions are mechanisms of mobilisation and integration of local affairs, efficient and effective service delivery.

Consequently, meaningful and sustainable forms of development are such that should be endogenous and the more organic approach is such that nurtures existing capacities through the mobilisation of local resources. This is because the donor-driven approach that relies on external intervention is often fraught with dangers (Ubels, Acquaye-Badoo, $\&$ Fowler, 2010). In other words, development should emanate from the will and desires of the people rather than the one imposed from outside (exogenous) and that the more superior developmental approach is the 'bottom up' rather than the 'top down' (Ekpe et al., 2013). 
Similarly, decentralisation which is the philosophy behind local government's existence is a corollary or the sine qua none of development. In principle, a well decentralised governmental system/structure is mostly able to increase the amount of resources available for public services. It can judiciously allocate these scarce resources across the nation optimally in the best interest of all and sundry (Adeoti, Olawale, \& Abdulkareem, 2014: Agba, Ocheni, \& Nnamani, 2014). There is a great relationship between decentralisation and economic growth because principles of centralisation are costly. They often lead government to provide public goods that diverge from the preferences of the citizens in particular areas, regions, provinces, and states (Alo, 2013; Akindele, Olaopa, \& Obiyan, 2009). Also Adenugba (2013), while making reference to Oates (2004) contends that when preferences vary among geographical areas, a uniform package chosen by a nation's government is likely to force some localities to consume more or less than they would have supposed to consume.

In essence, local government as agencies of decentralisation have their sources of revenue well cut out for them. These are the internal and external sources of revenues generation. The external sources are 20\% Federal Government Statutory allocation, 10\% State Internally Generated Revenues (IGR), Value Added Tax (VAT), Loans and Advances, Special Capital Grants, Investment Proceeds, and Aids. The Internally Generated Revenue (IGR) consists of sundry sources which can be grouped into market, social, health, and economic sources (Olaoye, 2008; Ojo, 2003; Rabiu, 2004). However, the increasing dependence of the local governments on federal statutory allocation has not only crippled their autonomy but has constrained and hamstrung them from effectively discharging their duties (Edogbanya, \& Jafaru, 2013; Chiedozie, 2004).

In fact, Atakpa, Ochei, \& Nwakwo (2012) observed that prior to the 1976 Local Government Reform, most local governments were able to maximise their IGR and perform their duties without recourse for assistance to higher authorities. The percentage of IGR to the total revenue was as high as $85 \%$ for some local governments between 1962 and 1983 (Atakpa et al., 2012). Since, the advent of centrally appropriated revenue occasioned by the oil boom, the dependency mentality on federal statutory allocation has prompted everyone to go to bed which had adversely affected the performance of local governments as veritable agents of rapid development and transformation (Olusola, 2011). 
In essence, the study intends to accomplish the following objectives:

1. identify the sources of revenue generation to the local government;

2. assess the impact of internally generated revenue on service delivery in the study area;

3. highlight the factors responsible for the narrow resource base of the local government

Ho: There is no relationship between IGR and service delivery in Ibarapa Central Local Government (ICLG) Oyo State, Nigeria.

\section{LITERATURE REVIEW AND CONCEPTUAL UNDERPINNINGS}

Scholarly works on the relationship between revenue generation and performance/service delivery are reiterating or espousing the role, significance challenges and importance of local government to the citizenry. The existence of local government can only be justified when and if it provides services to the public. The mere provision of such services notwithstanding, the issue is the effectiveness and the efficiency in the provision (Bello-Imam, 2010). Thus, for the discussion on literatures, studies are classified into three broad groups: the democratic-idealism perspective, service delivery perspective, and social-welfarism dimension. It is apt to contend that the taxonomy is simply for academic purpose; the three perspectives are not mutually exclusive but rather reinforcing.

The Democratic-idealism perspective is predicated largely on the works of the English social scientist, John Stuart Mills (1975) Utilitarianism, Liberty and Representative Government. This quoted by Olusola \& Siyanbola (2014), posits that the good form of government is representative government because it promotes liberty, equity, and justice. This philosophy is traceable to Pericles in his funeral oration which he charged to the fallen Athenian soldiers in the famous Peloponnesian war. "Athens is the school of mankind not because it loves wealth; but because it loves liberty, equity and justice". This idea makes men look beyond their immediate interest and recognises the just demands of other men. Also, it promotes political education, participation, and communication (Adenugba, \& Ogechi, 2013: Ola, 2010; Akhaine, 2009).

In other words, government is truly representative when everyone can take part. The local government offers the closest template for 
widespread consultation and participation (Obafemi, \& Bakare, 2007). This is further predicated on the assumption that politics and indeed development are about making choices through informed opinion, conflict management, and conflict resolution which are the priorities of local government (Abgani, \& Ugwoke 2013; Diejomioh, \& Eboh, 2016). Apart from the inculcation of democratic ideals of liberalism (election or selection), communal mobilisation and interest aggregation, local governments are training grounds for the political elite and government functionaries in the higher echelons (Oviasuyi, Idada, \& Isira Ojie, 2010; Onah, 2005).

However, the Service Delivery school of thought contends that the idea of democratic- idealism as enunciated by Mills (1975), and Panter Bricks (1953) do not apply to different political systems in the same manner especially in the face of modern realities. The crux of their theory is that the main purpose of local government is to provide services to the local people. Foremost among the scholars is the French social scientist Langood (1953), who contends that democracy is the affairs of the nation-state as issue of majority rule, equality, and uniformity are the norms (Ola, \& Tonwe, 2004; Fatile, 2009; Ibok, \& Tom, 2010). Local self government by contrast was parochial and concerned with local differences and exclusiveness/separatism. The two are diametrically opposed and it was only by historical accident that they had developed together in the $19^{\text {th }}$ century. He went on to contend that it is equally fallacious to perceive local government as a setting for political education and democracy (Ekpe, 2006).

Similarly, Moulin quoted by Olubukola \& Siyanbola (2014), points out that local government is so restricted while national goals are wider in scale. The local experience and knowledge are hardly appropriate to national affairs. Sharpe (1970) quoted from Olusola (2014) provided a very strong case for local government on the ground that it was the most efficient agent for providing those services that are essentially local. He suggests that the efficient performance of these services is so compelling that if local government does not exist, something else will be established in its place; meaning the institution is indispensable (Mbaya, Audu, \& Aliyu, 2014; Kizito, \& Fadila, 2015).

Furthermore, the position of Ibok (2014) is that the local level is the starting point of the struggle for the seizure of state power, its consolidation and usage. Needless to mention that it is after the capture of state power that it can be used for service delivery. This position 
however is tenuous and weak because it is not in all circumstances that the emergence of political leaders often begins at the local level. In fact, Afegbua (2010) contends that democracy is a process and is not a matter of geo-political enclaves. He contend that it is not in all circumstances that political leadership emerges from the local level and in fact, very many leaders that would preside on the authoritative allocation of values often emerge at the national level where impact and scope become wider. Nevertheless, whatever is the level of service provision is immaterial transformation which service delivery supposes to bring to peoples life. The essence of democracy according to Jeremy Bentham is the provision of the greatest good for the greatest number.

Empirical evidence also does not validate the contention that the local arena has only succeeded in breeding few national leaders. In fact, very many national leaders also started from local settings. It is also ludicrously at variance with fact to contend that local politics and democracy are antonyms. Democracy is a process and not peculiar to certain geo-political enclaves (Afegbua, 2010).

It is also pertinent to note that the Social-Welfarist approach unlike the Service Delivery Perspective, derives its strength not in its attack of the Democratic-idealism school of thought. Rather, it borrowed ideas from economics on the reasons behind the existence of public enterprises in spite of the numerous advantages of the private sector. The basic foundations were laid by Kenneth Arrow, Richard Musgrave, and Paul Samuelson's theory of public goods $(1955 ; 1954)$. This quoted by Adenugba \& Ogechi (2013) on public finance, provided the framework for what became accepted as the proper role of the state in the economy (Clark, \& Dorn, 2012; Nhema, 2015; Berejena, 2011).

Consequently, within its framework, three roles were identified for the government. The first is the role of the government in correcting various forms of market failures/distortions. The second is ensuring an equitable distribution of income and the third is seeking to maintain stability in the macro economy with full employment and stable prices (Lee, 2012). The theoretical framework is basically a Keynesian one which canvassed for an active role of the state in economic affairs. Thus the government is expected to step in where the market mechanism fails through its provision of various types of public goods services. Already, classical economics teaches that public goods will be underprovided if left to private market mechanism. This is because the private provider would under invest in such provision 
because the benefits accruable to him/her would be far lower than the total benefits to the society. The government and public functionaries were perceived as the custodians of public interest who would seek to maximise social welfare based on their benevolence. In a multi-level governmental setting, this role of the state in maximising social welfare is the basic ingredient for the theory of fiscal federalism (Blinder, 2008; Eberstadt, 2012; Dang, 2013).

In other words, each tier of government is then seen as seeking to maximise the social welfare of the citizens within its jurisdiction. This multi-layered quest becomes very important where public goods exist; the consumption of which is not national in character, but localised. In such circumstance, local outputs targeted at local demands by respective local jurisdiction clearly provide higher social welfare than central provision. This principle which Oates (2004), quoted by Adenugba \& Ogechi (2013), has formalised into the Decentralization Theorem, constitutes the basic foundation of what may be referred to as the first generation theory of fiscal decentralisation.

Similarly, public revenue decentralisation occurs when much of the money is raised centrally but part of it is allocated to lower level of government through some revenue-sharing formula otherwise known as administrative decentralisation. This is referred to as the 'Overlapping Authority Model' propounded by Wright (1978), as quoted by Edogbanya \& Jafaru (2013). The theory focused on situations where a different level of government provided efficient levels of output of public goods for those goods whose special patterns of benefits were encompassed by the geographical scope of their jurisdiction. Such situations came to be known as 'perfect mapping' or 'fiscal equivalence' as described by Adenugba \& Ogechi (2013).

Nevertheless, it was also recognised that given the multiplicity of local public goods with varying geographical patterns of consumption, there was hardly any level of government that could produce a "perfect mapping' for all public goods. Thus, there would be local public goods with inter-jurisdictional spillovers. For example, a road may confer public goods characteristics, the benefits of which are enjoyed beyond the local jurisdiction. The local authority may then under-provide for such a good. To avoid this, the theory then resorts to the traditional Pigouvian subsidies, requiring the central government to provide matching grants to the lower level government so that it can internalise the full benefits. Based on the following, the role of the government 
in maximising social welfare through public goods provision, came to be assigned to the lower tiers of government (Adenugba, \& Ogechi, 2013; Nwatie, 2004; Olaoye, 2006; Adeoti, Olawale, \& Abdulraheem, 2014; Mefor, 2009; Akindele, \& Olaopa, 2002).

\section{METHODOLOGY}

The study attempts to assess the impact of internally generated revenue on service delivery in Ibarapa Central Local Government Area, Oyo State (ICLCA). The methodology of the study is secondary source of data gathering consisting of internally generated revenue documents, departmental vote expenditure account documents, statutory allocation books, ledgers, cash books, and annual budgets. Others are annual reports and statements of account between 2010-2014. The area of study has been chosen because of its uniqueness as the food basket of Oyo State; the agrarian potentiality when fully explored, is capable of sustaining the local government through internally generated revenue without recourse to the monthly 'handouts' of the federal government. The other potentiality is the skill of the indigenes in historical traditional works of arts and craft, traditional cloth dyeing, weaving, blacksmithing, soap making, and other sundy indigenous manufacturing activities. The council also has the 'Towobowo' market which serves as a trade centre as well as nodal outpost for people in neighbouring states like Lagos, Ogun, Osun, Ondo, and Kwara just to mention a few. According to the National Population Commission (NPC) (2006), the census figure is one hundred and two thousand, nine hundred and seventy nine $(102,979)$. The land mass area is $440 \mathrm{sq} \mathrm{km}$ with over $75 \%$ of the land, arable throughout the year.

The data were analyzed using the analytical review method by inferring facts from data available.

\section{RESULTS AND DISCUSSION}

The study identifies the various sources of revenue generation available to Ibarapa Central Local Government, Oyo State, Nigeria. It evaluates or assesses the effects of internally generated revenue on the ability of the local government to discharge its statutory roles and 
duties. Hence the various sources of revenue generation are given in the various tables from year 2010-2014. In Table 5, the proportion of the various revenue sources as variables of total revenue is given. This indicates that the statutory allocation which is the federally or centrally generated and centrally appropriated revenue constitute the bulk of the revenue with 52.5\%. The Statutory Allocation was $\# 1676,607,400.94$. The implication of this is that the local government is not a viable tier of government because without the Federal Statutory Allocation, the local government is as good as dead.

Table 1. Stationary Allocation Table (2010-2014)

\begin{tabular}{|l|l|l|}
\hline \multicolumn{1}{|c|}{ S/N } & \multicolumn{1}{|c|}{ YEAR } & \multicolumn{1}{c|}{ ALLOCATION\# } \\
\hline 1. & 2010 & $328,303,874.78$ \\
\hline 2. & 2011 & $299,802,133.60$ \\
\hline 3. & 2012 & $359,792,895.72$ \\
\hline 4. & 2013 & $305,710,157.34$ \\
\hline 5. & 2014 & $382,998,339.50$ \\
\hline & TOTAL & $1,676,607,400.94$ \\
\hline
\end{tabular}

Source: Statutory Allocation CBN Record, Jan 2010 - Dec 2014.

Table 1 shows the total amount of revenue generated from federation account as statutory allocation to ICLG. The total amount was one billion, six hundred and seventy six million, six hundred and seven thousand, four hundred naira and ninety four kobo (\#1,676,607,400.94k).

Table 2. Revenue Table (2010-2014) allocated to ICLG

\begin{tabular}{|l|l|l|}
\hline \multicolumn{1}{|c|}{ S/N } & \multicolumn{1}{|c|}{ YEAR } & \multicolumn{1}{c|}{ ALLOCATION\# } \\
\hline 1. & 2010 & $34,026,241.55$ \\
\hline 2. & 2011 & $19,200,298.04$ \\
\hline 3. & 2012 & $34,815,173.38$ \\
\hline 4. & 2013 & $21,424,722.08$ \\
\hline 5. & 2014 & $26,780,902.54$ \\
\hline & TOTAL & $136,247,337.59$ \\
\hline
\end{tabular}

Source: Oyo State Ministry of Finance, Ibadan, 2015.

Table 2 shows the total amount of revenue allocated to ICLG from the 10\% state revenue between January 2010 and December, 2014. 
The total was one hundred and thirty six million, two hundred and forty seven thousand, three hundred and thirty seven naira and fifty nine kobo.

Table 3. VAT Revenue from Federation account (2010-2014)

\begin{tabular}{|l|l|l|}
\hline \multicolumn{1}{|c|}{ S/N } & \multicolumn{1}{|c|}{ YEAR } & \multicolumn{1}{c|}{ ALLOCATION\# } \\
\hline 1. & 2010 & $178,506,697.60$ \\
\hline 2. & 2011 & $136,088,344.25$ \\
\hline 3. & 2012 & $234,899,915.11$ \\
\hline 4. & 2013 & $155,699,017.41$ \\
\hline 5. & 2014 & $214,285,205.57$ \\
\hline & TOTAL & $919,449,179.94$ \\
\hline
\end{tabular}

Source: Statutory Allocation, CBN Record, 2014.

Table 3 shows that the total amount of VAT revenue allocation to ICLG between January 2010 and December 2014 was nine hundred and nineteen million, four hundred and forty nine thousand, one hundred and seventy nine naira, ninety four kobo (\#919,449,179.94).

Table 4. Excess Crude Oil Account from Federation Account (2010-2014)

\begin{tabular}{|l|l|l|}
\hline \multicolumn{1}{|c|}{ S/N } & \multicolumn{1}{|c|}{ YEAR } & \multicolumn{1}{c|}{ ALLOCATION\# } \\
\hline 1. & 2010 & $300,000,000$ \\
\hline 2. & 2011 & $2951,895.20$ \\
\hline 3. & 2012 & - \\
\hline 4. & 2013 & $150,000.00$ \\
\hline 5. & 2014 & - \\
\hline & TOTAL & $452,951,895.20$ \\
\hline
\end{tabular}

Source: Statutory Allocation, CBN Record, 2014.

Table 4 shows that the total amount of revenue generated from the federation excess crude oil account and allocated to ICLG is four hundred and fifty two million, nine hundred and fifty one thousand, eight hundred and ninety five naira, twenty kobo $(452,951,895.20)$.

From all internally generated revenue documents sourced in ICLG, internally generated revenue between 2010-2014 sum was \#6,806,595.32 (six million, eight hundred and six thousand, five hundred and ninety five naira, thirty two kobo). 
Table 5. The proportion of the different revenues to the total revenue

\begin{tabular}{|l|l|l|l|}
\hline \multicolumn{1}{|c|}{ S/N } & \multicolumn{1}{|c|}{ PARTICULAR } & \multicolumn{1}{|c|}{ AMOUNT (N) } & \multicolumn{1}{c|}{$\%$} \\
\hline 1. & Statutory allocation & $1,676,607,400.94$ & 52.5 \\
\hline 2. & Value added tax & $919,449,179.94$ & 28.8 \\
\hline 3. & Excess crude oil & $452,951,895.20$ & 14.2 \\
\hline 4. & Internally generated revenue & $6,806,595.32$ & 0.21 \\
\hline 5. & State revenue (10\& allocation) & $136,247,337.59$ & 4.27 \\
\hline & Total & $3,192,062,409$ & 100 \\
\hline
\end{tabular}

Source: own work, 2016.

In order to balance the analysis, Table 5 indicates capital and recurrent expenditures undertaken between 2010-2014.

Table 6. Capital and Recurrent Expenditures Record

\begin{tabular}{|l|l|l|l|l|}
\hline S/N & \multicolumn{1}{|c|}{ Year } & Capital expenditure (N) & \multicolumn{1}{|c|}{ Recurrent (N) } & \multicolumn{1}{c|}{ Total (N) } \\
\hline 1. & 2010 & $300367,450.89$ & $259940,823.93$ & $560,308,274.83$ \\
\hline 2. & 2011 & 389123382.65 & $316,296,001.76$ & $705,419,384.41$ \\
\hline 3. & 2012 & $207,383632.45$ & $402,164,974.99$ & 609548607.44 \\
\hline 4. & 2013 & $180,401157.34$ & $131,980609.06$ & $312381,766.40$ \\
\hline 5. & 2014 & $175,311683.23$ & 211812216.08 & $387,123,899.31$ \\
\hline & TOTAL & $1,252,587,306.56$ & 1322194625.83 & $2,574781932.39$ \\
\hline
\end{tabular}

Source: ICLG Statement of Accounts, 2015.

This table has indicated that the expenditure has constantly surpassed the potentialities of revenue sources, particularly their IGR. This arises because of the great chasm between the need of the local council and their fiscal capacity. For example, between 2010 and 2014 the total revenue was $3,192,062,409$ while the expenditure was $2,574,781,932.39$ giving a paltry balance of $617,280,477$. The $\%$ of capital expenditure to total expenditure is 48.6 which implies that $51 \%$ of expenditure profile is on recurrent expenses. With this account, the local government cannot offer much in terms of social services and development projects. The implication of this is in the poor standard of living of the citizenry which are manifested in decadent infrastructure and deficient service deliveries or their virtual obliteration.

The data in Table 7 shows that in the performance of statutory duties, there is a high degree of dependence on statutory allocation from the federation account by the local government. This is validated by the $52.5 \%$ dependence whereas, its internally generated revenue 


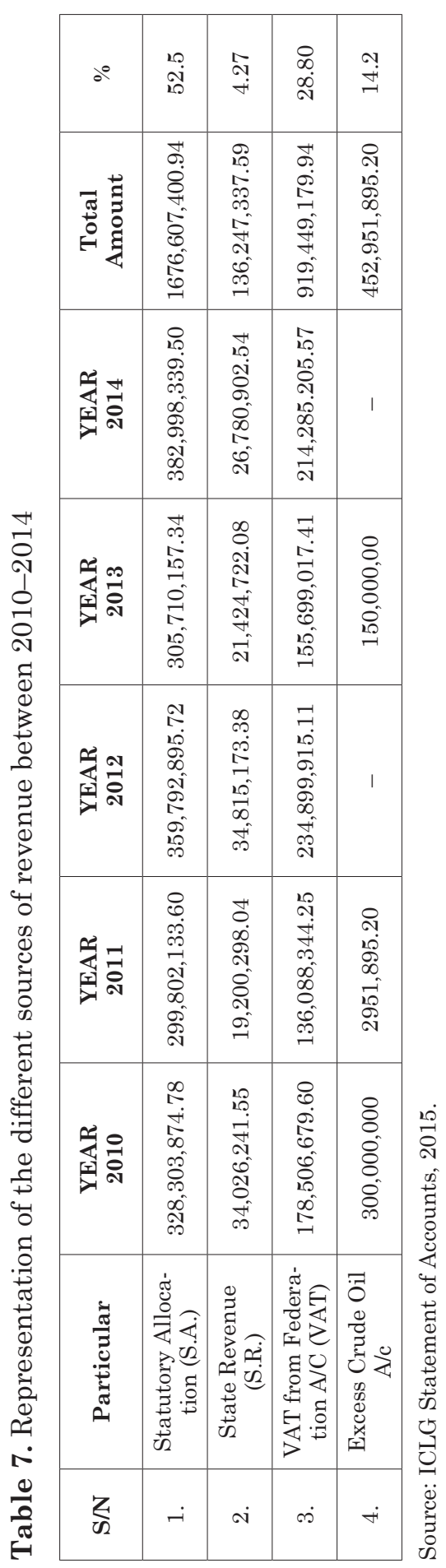


of $0.21 \%$ is nothing to write home about which implies that whenever the federal allocation does not forth come, the local government total activities will be in paralysis.

All internally generated documents sources in ICLG summing up the value of Internally Generated Revenue between 2010 and 2014 to \#6,806,595.32 (six million, eight hundred and six thousand, five hundred and ninety five naira, thirty two kobo stood at $0.21 \%$ ).

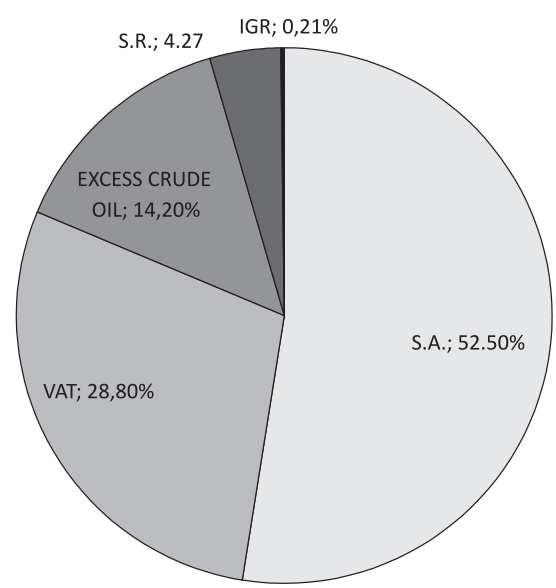

Figure 1. The pie chart shows the proportional representation of the different sources of revenue between 2010-2014

Source: own source, based on: Inferential Statistical Analysis.

Ho: there is no relationship between internally generated revenue (IGR) and service delivery in ICLG, Oyo State

\section{Inferential statistical analysis coefficients}

Table 8. Anova Test

\begin{tabular}{|c|c|c|c|c|c|}
\hline \multirow{2}{*}{$\begin{array}{l}\text { Internally generated revenue } \\
\text { has no significant relationship } \\
\text { with service delivery }\end{array}$} & \multicolumn{2}{|c|}{ Unstandardised coefficients } & \multirow{2}{*}{ Beta } & \multirow{2}{*}{$\mathrm{T}$} & \multirow{2}{*}{ Sig. } \\
\hline & B & Std. error & & & \\
\hline (Constant) & $\begin{array}{l}-.577 \\
3.596\end{array}$ & 1.060 & -.384 & $\begin{array}{c}-1.763 \\
3.392\end{array}$ & $\begin{array}{l}.095 \\
1003\end{array}$ \\
\hline
\end{tabular}

ANOVA

\begin{tabular}{|l|c|c|c|c|c|}
\hline \multicolumn{1}{|c|}{ Model } & Sum of square & $\mathrm{df}$ & Mean square & $\mathrm{F}$ & Significance \\
\hline 1. Regression & 4.286 & 4 & 17072 & & \\
Residual & 7464 & 15 & .498 & 2.154 & $1124 \mathrm{a}$ \\
Total & 11750 & 19 & & \\
\hline
\end{tabular}

Source: ANOVA TABLE. 
The $\mathrm{p}$-value is greater than the level of significant 0.051 , hence we reject the Ho: There is no significant relationship between internally generated revenue and service delivery in ICLG and accept H1 that there is significant relationship between internally generated revenue and service delivery in ICLG.

The test statistics is the F-Value of 2.154 in the table above using an $\infty$ of 0.05 ; There is F0.05 4.15 = 3.06 (F distribution table).

Since the test statistics is greater than the critical value, we have rejected the null hypothesis of equal population means and concluded that there is no statistically difference among the population means.

The $\mathrm{p}$-value of 2.154 is 0.095 , so that the test statistics is not significant at that level. As a result, the p-value is greater than the level of significant relationship between internally generated revenue and service delivery in ICLG and accept Hi that there is a significant relationship between internally generated revenue and service delivery in ICLG. This is because without internally generated revenue there cannot be a viable local government.

\section{CONCLUSION}

The role and importance of internally generated revenue to local government administration cannot be overemphasised. In fact, it is not an overclaim to contend that IGR is an euphemism for local government administration. This is because without its viability, the local councils cannot achieve its goals and objectives. This is the case with ICLG that has acutely found it difficult to execute its developmental programmes when statutory allocation is not forthcoming due to economic challenges confronting the nation; the activities of the local councils often come to a standstill.

Similarly, there are other challenges like visionless leadership, incompetent manpower, terrible fund generation strategies, improper record keeping, political patronage, nepotism, prebendalism, patrimonialism and indiscriminate intervention from the federal and particularly the state governments (Uhummuangho, 2013). These challenges have to be tackled headlong in order for the public to repose an implicit confidence in the councils as the grassroots government closest to the people. It is with willingness that local populace will pay their taxes and fulfil other financial obligations the moment local 
government service deliveries are prompt, adequate, effective, efficient, and sustainable. The domino and multiplier effect of these symbiotic relationships will enable the local councils to be more result oriented. The result indicates with the acceptance of $\mathrm{Hi}$ which contends that there is significant relationship between Internally Generated Revenue and Service Delivery that is the IGR that actually makes the local government. However, it is not strong enough to make the citizens repose their confidence that it is a tier government worthy enough to attract their taxes and rates. Consequently, policy measures have to be institutionalised in order to boast the internally generated revenue of the study area. Hence the following recommendations have been presented below.

\section{RECOMMENDATIONS}

First, Strategy must be put in place to checkmate against corrupt practices and financial leakages, resource conduit pipes and economic loopholes. The success or failure of any local government largely depends not only on availability of financial resources, but effective and judicious utilisation of the resources.

Second, to whom much is given, much is expected. Local government should not be a failure in its provision of social amenities and basic infrastructure to the public. Once, there is concrete facilities provision, commensurate with tax rates and levies of the public, the commitment on the part of the public to pay will be willingly and natural.

Third, commercial plantation farms and agro-allied industries that can provide job opportunities for the teeming unemployed populace can be established. There must be a tremendous purchase of modern farm implements like tractors, combined harvesters, seedlings, silos/storage facilities and subsidised fertilizers just to mention a few. Small and medium scale enterprises that will use arable crops from the areas as raw materials will not only get the people employed but confer comparative advantage on the council.

Fourth, there should be a complete overhaul of the local government system, structure, roles, and ideology. Competent hands should constitute the manpower and be sufficiently remunerated. How it works in countries like UK and USA where public management scholars promoted the idea, and Margaret Thatcher and Ronald 
Reagan incorporated the idea into public governance is by borrowing ideas from the private sector and market based principles. This is to ensure the 3Es of management which are economy, efficiency, and effectiveness. Resourcefulness should not be sector biased and it does not matter in whose hands the infrastructure lies, what matters in every enterprise is the quality of the management (Owen,1999; Esu, \& Inyang, 2008).

Finally, new laws have to be promulgated that will empower the councils as the third leg in the tripod of federalism. This has to be with all the appurtenances of authority, autonomy, and independence that will enable them to function as agents of decentralisation rather than that of deconcentration.

\section{REFERENCES}

Abgani, B.J., \& Ugwoke, R.O. (2014). The State Joint Local Government Accounting System Challenges on Rural Development in Nigeria. Research Journal of Finance \& Accounting, 5(18). Retrieved from http: / / www.iiste.org/journals/index.php/RJFA/article/download16219/16602, [access 24.09.2017]. Adedokun, A. (2102). Local Government Tax Mobilization and Utilization in Nigeria: Problems and Prospects. Retrieved from http://visar.csustan. edu/aaba/Adedokun.pdf, [access: 24.09.2017].

Adenugba, A.A., \& Ogechi, C.F. (2013). The Effect of Internal Revenue Generation on Infrastructural Development: A Study of Lagos Internal Revenue Service. Journal of Educational and Social Research, 3(2), 419-436.

Adeoti, J.O., Olawale, Y.A., \& Abdulraheem, M. (2014). A Comparative Analysis of SWOT on Sources of Internally Generated Revenue in Oyo State Local Government. International Journal of Research in Management \& Business Studies, 1(2).

Adi, A.A., Magaji, I.Y., \& Eche, E. (2015). Internal Revenue Generation in Taraba State, Nigeria: Problems and Prospects. International Journal of Economic Commerce and Management, 3(2), 1-13.

Afegbua, S.I. (2010). Democracy, Civil Society and Governance in Nigeria. African Journal of Institutions and Development, 5(8), 305-312.

Agba, M.S., Ocheni, S., \& Nnamani, D.O. (2014). Local Government Finance in Nigeria: Challenges and Prognosis for Action in a Democratic Era (1990-2013). Journal of Good Governance and Sustainable Development in Africa, 2(1), 84-96. 
Akhaine, S.O. (2009). Local Government Administration in Nigeria. Old and New Vision. Lagos: Centre for Constitutionalism and Demilitarization (CENCOD).

Akindele, S.T. (2004). Political Mobilization for Rural Development and a Stable Nigerian Democratic Republic: An Indepth Examination of the Role of Local Governments. Journal of Human Ecology, 162(2), 99.

Akindele, S.T., Olaopa, O.O., \& Obiyan, A.S. (2009). Financial Autonomy and Consistency of Central Government Policy Towards Local Governments. International Review of Administrative Sciences, 7(5), 311-332.

Akinoye, S. (2013). Federal Allocation: The Nightmare Is Not Over. The Nation Newspaper, Monday, October 14.

Alo, E.N. (2013). Fiscal Federalism and Local Government Finance in Nigeria. World Journal of Education, 2(5), 19-27.

Arrow, K., Musgrave, R., \& Samuelson, P. (1954; 1955), quoted from Adenugba, A.A., \& Ogechi, C.F. (2013). The Effect of Internal Generation on Infrastructural Development: A Study of Lagos State Internal Revenue Service. Journal of Education and Social Research, 3(2), 419-436.

Atakpa, M., Ocheni, S., \& Nwakwo, B.C. (2012). Analysis of Options for Maximizing Local Government Internally Generated Revenue in Nigeria. International Journal of Learning and Development, 2(5), 94-104.

Bello-Imam, I.B. (2010). Intergovernmental Relations in Nigeria in Bello-Imam. Local Government Finance in Nigeria. Ibadan: University Press.

Berejena, S. (2011). An Overview of Public Sector Reforms in Zimbabwe. Paper presented at the OSSREA Regional Conference on Three Decades of Public Sector Reform in Sub Saharan Africa, Cresta - Oasis hotel, Harame, 4-6 July.

Brough, P. (2012). Systemic Capacity Building: A Hierarchy of Needs. London: Oxford University Press.

CBN (2015). Annual Report and Statement of Accounts for the Year Ended 31st December 2014. Abuja: Central Bank of Nigeria.

CBN (2010). Annual Report and Statement of Accounts for the Year Ended 31st December 2010. Abuja: Central Bank of Nigeria.

Chiedozie, A.O. (2004). Local Government Administration and Rural Development in Nigeria. Aba: Kalu Press.

Coker, M.A., Eteng, F.O., Agishi, T.V., \& Adie, H.I. (2015). Challenges of Expanding Internally Generated Revenue in Local Government Council Areas in Nigeria. Journal of Sustainable Development, 8(9), 79-88.

Coker, M.A., \& Adams, J.A. (2012). Challenges of Managing Local Government Finance in Nigeria. Research on Humanities and Social Sciences, 2(3), 1-12. 
Dang, D.Y. (2013). Revenue Allocation and Economic Development in Nigeria: An Empirical Study. Retrieved from http:sgo.sagepub.com/content/3/3/2158244013505602, [access: 24.09.2017].

Dorn, J.A. (2012). The Scope of Government in a Free Society. Carto Journal, 32(3), 629-642.

Diejomaoh, I., \& Eboh, E. (2010). Local Government in Nigeria: Relevance and Effectiveness in Poverty Reduction and Economic Development. Journal of Economics and Sustainable Development, 1(2), 12-28.

Eboh, E.C., \& Lemchi, J.I. (2010). Business Environment in Nigeria States: Tackling the Security Challenges. Enugu: African Institute for Applied Economics.

Edogbanya, A., \& Ja'afaru, G.S. (2013). Revenue Generation: Its Impact on Governmental Effort (A Study of Selected Local Council in Kogi East Senatorial District). Global Journal of Management and Business Research Administration and Management, 3(4), 13-26.

Ekpe, A.N. (2006). The Substance of Local Government Administration in Nigeria (Theory and Practice). Lagos: Asbot.

Ekpe, A.N., Daniel, E.E., \& Ekpe, A.M. (2013). Analysis of Performance Appraisal System of the Nigeria Public Sector Organizations. Journal of Humanities and Social Sciences, 18(3), 49-54.

Esu, B.B., \& Inyang, B. (2009). A Case for Performance Management in the Public Sector in Nigeria. Journal of Business and Management, 4(4), 25-26.

Ibok, E., \& Tom, E. (2010). Introduction to Local Government Administration in Nigeria: Contemporary Issues. Nigeria: Edinson.

Ibok, E. (2012). Governance and Project Implementation in Local Government in Nigeria. In: C.O. Bassey, \& G.O. Ozumba, Political Science and Introductory Reader. Lagos: Concept Publication.

Ibok, E. (2012). Alternative Sources of Revenue Generation for the Development of Rural Areas in Africa: The Nigeria Experience. International Journal of Social Sciences, 6(5), 1-11.

Ibok, E. (2014). Local Governance and Service Delivery in Nigeria. Caribbean Journal of Service and Technology, 2(2), 536-541.

King, M.C. (1988). Localism and nation-building. Ibadan: Spectrum.

Kizito, E.U., \& Fadila, J. (2015). The Challenges of State and Local Government Joint Account and its Impact on Rural Development in Nigeria. Retrieved from http:www.academia.edu/7977731. [access: March 7, 2015].

Langood (1953), quoted from Olusola, O.O. (2011). Boosting Internally Generated Revenue of Local Governments in Ogun State, Nigeria. European Journal of Humanities and Social Sciences, 8(1), 338-348. 
Lee, D.R., \& Clark, J.R. (2013). Market Failures, Government Solutions and Moral Perceptions. Carto Journal, 33(2), 1-25.

Mbanefo, G.F., \& Bello-Imam, I.B. (2010). Potential Revenue Services for Local Governments. In: I.B. Bello-Imam (ed.), Local Government Finance in Nigeria. Ibadan: University Press.

Mbanya, P.Y. (2009). Elements of Comparative Government and Administration. Kaduna: Ray Publishing Company.

Mbaya, P.Y., Audu, R.A., \& Aliyu, M. (2014). Administrative Efficiency as a Strategy for Improved Local Government Effectiveness in Borno State, Nigeria. Global Journal of Political Science and Administration, 2(5), 9-22.

Mills, J.S. (1975). Consideration of Representative Government. London: Oxford University Press.

Nhena, A.G. (2015). Privatization of Public Enterprises in Developing Countries: An Overview. International Journal of Humanities and Social Sciences, 5(9), 247-256.

Obafemi, M.A., \& Bakare, H.O. (2007). Effects of Social Economic Factors on Rural Water Supply Schemes: Management Sustainability in Nigeria. Journal of Arts and Social Sciences, 9, 84-88.

Ojo, O. (2009). Efficient Management for Local Government: The Nigerian Experience. Bulletinne Universitajii Petrol-gazedin ploieti, Lxi (2), 36-44.

Ojo, S. (2003). Principles of Nigeria Taxation. Lagos: Sagriba Publication.

Ola, R.F., \& Bello-Imam, I.B. (2010). Resident's Percpetion on Local Government Services. In: I.B. Bello-Imam (ed.), Local Government Finances in Nigeria. Ibadan: University Press.

Olaoye, C.O. (2008). Analysis of Government Finance (1st Edition). Ilorin: Clemart Publishers.

Olusola, O.O. (2011). Boosting Internally Generated Revenue of Local Governments. European Journal of Humanities and Social Sciences, 8(1), 338-348.

Olusola, O.O., \& Siyanbola, T.T. (2014). The Role of Internally Generated Revenue of Local Governments Administration in Nigeria. Journal of Business Management and Social Science Research, 3(5).

Onah, F.E. (2007). Fiscal Federalism in Nigerian. Nsukka: Great AP Publishers.

Oseni, M. (2003). Internally Generated Revenue in Nigeria: A Panacea for States Development. European Journal of Humanities and Social Sciences, 21(1), 1050-1066.

Oviasuyi, P.O., Idada, W., \& Israojie, L. (2010). Constraints of Local Governments Administration in Nigeria. Journal of Social Sciences, 24(2), 81-86.

Owen, H. (1999). Public Management and Administration - An Introduction. London: Macmilllian. 
Panter-Brick, K. (1953). Local Government and Democracy: A Rejoinder. London School of Economics and Political Science, 31(4), 317-437.

Rabiu, S.A. (2004). Personal Income Tax in Nigeria: Procedures and Problems (1st Edition). Lagos: Adebanjo Publishers.

Sharpe and Moulin (1970), quoted from the work of Olusola, O.O., \& Siyanbola, T.T. (2014). The Role of Internally Generated Revenue of Local Governments Administration in Nigeria. Journal of Business Management and Social Science Research, 3(5).

Ubels, J., Acquaye-Badoo, N., \& Fowler, A. (2010). Capacity Development in Practice. Journal of Development, 5(2), 1489-1620.

Uhunmwangho, S.O., \& Stanley, A. (2013). Problems of Revenue Generation in Local Government Administration in Nigeria. Business and Management Research Journal, 2(3), 89-96.

Wright (1978), quoted from Edegbonya, A. \& Ja'afaru, G.S. (2013). Revenue Generation: Its Impact on Governmental Effort (A Study of Selected Local Council in Kogi East Senatorial District). Global Journal of Management and Business Research Administration and Management, 3(4), 13-26. 


\title{
ANALIZA GENEROWANIA DOCHODÓW ORAZ ŚWIADCZENIA USKUG W CENTRALNYM SAMORZĄDZIE LOKALNYM IBARAPA, IGBOORA, STAN OYO (2010-2014)
}

\begin{abstract}
Abstrakt
Tło badań. Badanie koncentruje się na relacjach pomiędzy generowaniem przychodów a świadczeniem usług w Ibarapa Centralnym Samorządzie Lokalnym, Igboora, Oyo, Nigeria (2010-2014). Określa różne źródła generowania dochodów samorządu terytorialnego i analizuje wpływ każdego z nich na świadczenie usług. Analizuje również czynniki stymulujące skuteczność różnych źródeł i zaleca, w jaki sposób można je poprawić.
\end{abstract}

Metodologia. Samorządy uzyskiwały wewnętrznie dokumenty dochodowe, wyodrębnione księgi rachunkowe wydatków, rejestry alokacji ustawowej, księgi rachunkowe i roczne prognozy budżetowe w latach 2010-2014. Do interpretacji danych wykorzystano opisowe narzędzia statystyczne dotyczące procentów, rozkładu częstotliwości i rozkładu tabel, a także inferencyjnych narzędzi statystycznych analizy wariancji (ANOVA).

Kluczowe wnioski: Wynik testowanej hipotezy $(\mathrm{F}=2,154$ przy 0,05 poziomie istotności) wskazuje, że istnieje związek między dochodem wewnętrznym (IGR) a dostawą usług w Centralnym Samorządzie Lokalnym Ibarapa, Igboora. Jednak związek nie ma pożądanego efektu w samorządzie lokalnym, ze względu na niewielką sumę generowanego dochodu wewnętrznego (IGR). Heurystyczne wartości badania sa trzykrotnie faliste. Po pierwsze, pogłębiona została wiedza na temat roli i znaczenia samorządów lokalnych jako agencji finansów publicznych. Po drugie tekst dostarcza również wiedzy na temat sposobów opracowywania strategii na rzecz poprawy przychodów wewnętrznie generowanych przez samorządy lokalne. Po trzecie, dostarcza informacji, jak rzadko rozsądne, sprawne i efektywne jest zarządzanie w sferze finansów przez lokalne samorządy.

Słowa kluczowe: efektywność, skuteczność, przychody wewnętrzne, lokalne władze Ibarapa, Nigeria 